\title{
A Brief Analysis of Maker and Entrepreneurship
}

\author{
Min Qian ${ }^{1}$ and Xiaoxue Zhao ${ }^{1}$ \\ ${ }^{1}$ School of Economics and Management, Nanjing University of Science and Technology, Nanjing \\ 210094, China \\ 1684356170@qq.com, 1453663598@qq.com
}

Keywords: Maker; Entrepreneurship; Public space; Entrepreneurial opportunity

\begin{abstract}
Innovation has always been a driving force for the development of the times. With a steady stream of innovation, it can bring lasting development and vitality for a country and a nation. This paper set off to start business, from what is off the record, set off to the analysis of entrepreneurial background, from creating ways to entrepreneurship and entrepreneurship to achieve record off from the record space may result in the problem of these four aspects to describe the feasibility and difficulty to realize the business from a customer and hope that through this article can provide a perspective for the future development of Chinese off the record, hoping to Chinese innovative development.
\end{abstract}

\section{The Literature Review}

Maker refers to that people who try to turn ideas into reality out of interests[1]. universal significance, makers love life and put their ideas into practice to go through some means of science and technology, and to share life. And they bring to people's life for the new "play" attitude. Creating itself is not a commercial color, they just focus on their own lives, they tend to create to enrich their life, it can be said that this is the group's living state and lifestyle choices. But in the China, "maker" and "public entrepreneurship, innovation" are together, especially with the concept of innovation, entrepreneurial human[2]. Which is Chinese in such an environment, a state with the formation of the characteristics of China, countries hope to take these creative thinking into reality and form a product or service to stimulate economic development.

Enthusiastic About Entrepreneurship. Makers is a group, they love innovation, are not satisfied with the current way of life. They are willing to in accordance with their own ideas to create some new things to enrich their lives. They will use the mobile Internet era they created something to share with the public. They are keen to create the courage to practice, and willing to share becomes the typical characteristics of this group[3].

Treat Life with a Libertinism Attitude. Makers love out of the ordinary way of life. They love to "play", or that they are living, they will have the attitude into practice, create a lot of interesting things, to enrich themselves and the lives of people around.

The Majority of Young People. Makers age span, but most are concentrated in the younger group, Because these young people love the "play". For the emerging things more easy to accept, but they are creators of much more new things.

Pursuit of Commercial Value Incompletely. The original definition of the group of makers is not related to business atmosphere. They love to create new things, just to satisfy their own playful attitude towards life, but also a way of life of their choice. The era of technology, they can put their ideas into products or services on the public services to the public. However, many of them is more likely to hold a share of the attitude, not completely when do the commercial thing to do, otherwise they would not be fully known as off the record, they will probably be called entrepreneurs, so that is not exactly hit off the pursuit of commercial value.

\section{Background of the Development from Maker to Entrepreneurship}

Put forward the Public Entrepreneurship and Innovation. Premier Li Keqiang, chairman of the State Council, said at the opening of Davos on September 10, 2014. "China will always be a big 
country for innovation and innovation." China will always be a big country, , To promote the development of China's economic science, in 9.6 million square kilometers of land set off a 'public entrepreneurship', 'grassroots business' new wave, the formation of' innovation ',' everyone innovation 'new situation'. On December 3, 2014, the premier of the State Council executive meeting put forward that "it is necessary to mobilize social innovation to create a passionate 'multiplication' through the government's decentralization." The Chinese economy is going to transition to the middle and high end, Thousands of Chinese people's wisdom, the 'people' more fully motivated to mobilize ". November 20, 2014 the first World Internet Conference, the Prime Minister once again advocated to "promote the Internet to share a total of governance, to promote public entrepreneurship innovation". March 3 to March 15, 2015, Premier Li Keqiang in the government work report pointed out that the "public entrepreneurship, innovation" to promote the Chinese economy to continue to move forward one of the "double engine" .

"Public entrepreneurship, innovation" era can be said that the typical model of innovation 2.0 model[4]. Researchers point out that innovation is in fact accompanied by the increasing boundaries of innovative network cooperation and the deepening of the development of open innovation theory. The public communicates to share and eventually forms the innovation through the Internet platform. Is the industrialization of innovation results, refers to the entrepreneur to own the resources to optimize the integration, thus creating greater economic or social value of the process[5]. Among them, the "business" should be understood from the broad sense. Through the innovation and creative achievements of the self-made and share, fully demonstrated the public entrepreneurship, the vitality of innovation, creating a whole society to participate in innovation and sharing of the atmosphere, forming a fusion of DIY, create and share as the core The value of the creative culture. The main body of entrepreneurship gradually from small to public, innovation and entrepreneurship from the elite to the public, more and more "grassroots" groups appear, innovation and entrepreneurship has formed a value-oriented, lifestyle and the times.

The Appearance of Maker Space. The public space was a new concept put forward by Premier Li Keqiang at the State Council executive meeting on January 28, 2015, after inspecting the civil space in Shenzhen. The meeting pointed out that in the space, innovation and other factories on the basis of hatching model, vigorously develop the market, specialization, integration, network of "public space" to achieve innovation and entrepreneurship, online and offline, incubation and investment Combined, for small micro-innovation business growth and personal entrepreneurship to provide low-cost, convenient, all-factor open integrated service platform [11]. Public space for the start-up of small and medium enterprises and teams, with other forms of products do not have the unique value: First, the public space in the highly uncertain business start-up period to provide a flexible and scalable office rental model. This stage of the team or business is likely to grow rapidly, but also a great probability of half-way failure or give up their own, so a fixed area for a long time the lease is not an early waste is the growth of the shackles, and on demand Strain flexible rental model, relatively speaking, more savings in total cost of ownership. Second, with other entrepreneurs to share conference rooms, administrative staff, print equipment and other sporadic needs of the resources required, pay-per-view, even if the single price higher, the overall view is more cost-effective. Thirdly, for public support with government support and subsidies, start-ups can use lower prices and even free time-limited jobs, and are more likely to understand and receive support from other government industry support policies. Fourth, the public space is with other entrepreneurs, peers or industry upstream and downstream partners to communicate with each other, can inspire and encourage each other. Fifth, due to the aggregation of similar people and teams, the public space may provide a highly targeted and standardized value-added service. Sixth, because the public space gathered a group of industry-specific start-up team, it may attract some valuable resources for the start-up team, such as media, investors and other third-party services, making the 
entrepreneur can be more convenient, lower cost To obtain investment and financing and other services. Seventh, for the start-up and growth of enterprises and teams, they can promote cooperation between each other or even reorganization[6].

\section{The way from the Maker to the Entrepreneurship}

The Government to do the basic Service Work. First of all, the government should clear the way for the entrepreneur to clear barriers to innovation and entrepreneurship. The introduction of decentralization, reorganization of the combination of further measures to increase efforts to improve the administrative examination and approval, registered capital, market barriers, listing and financing and a variety of "roadblocks" to stimulate market vitality. Secondly, the government should strengthen its services and introduce government services for innovative entrepreneurs. More to understand the actual needs of entrepreneurs, the introduction of entrepreneurs really care, to meet the needs of entrepreneurs to support the policy. Finally, the government should strengthen the guiding function, guide the appropriate social resources to participate in innovation and entrepreneurship[7].

Play the Role of Advantages of Large Enterprises. Large enterprises have more high-quality innovative resources, including high-end talent, scientific research conditions, rich funds, in the public entrepreneurship, the era of popular innovation should play a more important role. First, we must continue to increase R \& D capital investment, improve technology research and development capabilities, do innovation-driven practitioners. Second, we must play a platform advantage, and actively promote internal entrepreneurship and provide technical services.

Colleges should Cultivate Talents according to the needs of the Market. University institutions in the innovation and entrepreneurship ecological circle to bear the output of talent and scientific and technological achievements of the important functions, play the role of innovative business source of living water. Scientific and technological achievements to the market can be called innovation, to meet the requirements of the students can be called talent, which determines the institutions of higher learning and scientific and technological achievements in output to give full consideration to the needs of the market. Colleges and universities only and the market fully linked from the perspective of the needs of the industry personnel training, from the perspective of market demand output, innovation circle of talent circle, the knowledge cycle can be successfully completed.

Grasp the Advantages of Public Space. Public space is the space gathering of innovative projects and entrepreneurial teams, and is an innovative form of service products[8], for entrepreneurs to provide work space, cyberspace, social space and resource sharing space, specifically to provide financial Investment, project training, publicity and promotion, industrial channels, open space, public technology and other services, and the idea and ideas into a project and products. Makers create a guest in-depth create space, mutual cooperation with each other, resulting in ideological collision, to stimulate more innovation.

\section{Potential Problems}

Although the country provides a good business environment, put forward the construction of a space, but in the process of creating to entrepreneurship is difficult, not overnight, change a customer identity in the process of the development, there will be a lot of different difficulties waiting for them.

Decline in Specialization. On the one hand, with the support of the national policy, the space for the public to expand at a very rapid pace, resulting in the management level and professional quality of the creative space is difficult to match. Due to the pre assessment inadequate, poor planning, positioning, ignoring the regional differences and characteristics of the industry, resulting in the 
public record space positioning service is insufficient, incomplete facilities, scientific management mode is not perfect, the public record space easily made "shell", "grocery store", the professional degree of decline[9]. On the other hand, because the idea deviation of planners and organizers, will the public record space as a way to digest idle property site, resulting in the public record space blindly, excess supply, blindly staking is easy to form a new round of resource preemption and waste, and easy to form a new political project.

Single Profit Model. Most of China's public space is facing the problems of immature commercial operation mode, imperfect market mechanism, market capital being not activated and sustained profit difficulty[10]. In higher housing prices, the public space rent costs and operating costs higher, high costs and high service gap, resulting in the creation of space is difficult to explore a mature profit model.

Regional Imbalanced Development. Affected by the regional economic development is not balanced, the public record of space cognition, influencing factors of policy support, the development of China's innovation and entrepreneurship and mass public record space shows obvious regional imbalance[11]. In addition to Beijing, Shanghai, Guangzhou, Shenzhen several first-tier cities, Hangzhou, Nanjing, Wuhan, Chengdu, Xiamen etc. the developed economy, high-tech investment aggregation, active areas of entrepreneurship and innovation more active, has emerged a large number of distinctive public record space. In contrast, area is remote, underdeveloped small Midwestern city, its industrial development mode is backward, lack of innovation, low economic efficiency, the "double" bonus to benefit. However, the lack of personnel, shortage of resources, inadequate understanding, support the development of a variety of factors such as limit is difficult to place these in the public record space, using the public record space can stimulate the transformation of industries and economic benefits still have a long way to go.

\section{Conclusion}

This article shows that under the context of China, entrepreneurs are faced with the strong support of the state environment, through the creation and development of space for the fans to provide a good entrepreneurial environment, hope that they can through the successful To achieve its own value and hope to promote the country's continuous progress and development.

\section{Reference}

[1] D.Q. Ding, On Makers and Historical Genes of the Maker Culture, [J].Social Sciences of Beijing, (2015) No.8, p. 22-28. (in Chinese)

[2] Y.M. Wang, A.M. Y, From the passenger space to the public space: Functional Model Based on Innovation 2.0 and Service Path, [J]. e-Education Research, (2015) No.11, p.5-12. (in Chinese)

[3] Y. Xie, X. Tong, Y.F. Cai, Innovation and Upgrading in Manufacturing: Investigation on the Maker Community in Shenzhen, [J]. Science \& Technology Progress and Policy, Vol. 32 (2015) No.2, p. 59-65. (in Chinese)

[4] L. Luo, Z.T. Zhu, Makerspace 2.0: Designing Makerspace Based on the O2O Architecture, [J]. Open Education Research, Vol. 21 (2015) No. 4, p.35-43. (in Chinese)

[5] Z.Y. Liu, Q.X. Chen, Y. X, The Conceptual Model and Theoretical Analysis of Crowd Innovation, [J]. Science of Science and Management of S.\& T, Vol. 36 (2015) No. 2, p.52-61. (in Chinese)

[6]S. Chen, L.Y. Xiang, R.J. Yu, Co-maker Space Entrepreneurship Ecosystem: Features, Structure, Mechanism and Strategy_Case Study on Hangzhou Dream Town, [J]. Journal of Business Economics, Vol. 289 (2015) No. 11, p.35-43. (in Chinese)

[7] X. Y, D.Y. Lu, An Analysis of the Development Strategy of Makerspace, [J]. Journal of Commercial Economics, (2016) No. 7, p.103-104. (in Chinese)

[8]J. Wu, Z.L. Zhan, H.S. Zhou, Theoretical Interpretation of "Maker Space" and Countermeasures, [J]. Science and Technology Management Research, (2016) No. 6, p.56-56. (in Chinese) 
[9] W.F. Zheng, M.H. Cui, Research on the Combination of Passenger Mode and Strategic Change and the Way to Realize, [J]. Science \& Technology Progress and Policy, Vol.32 (2015) No.17, P.27-30. (in Chinese)

[10] T.Y. Li, An Analysis of Operating mode of makerspace, [J]. Chinese \& Foreign Entrepreneurs, (2016) No.8, p.246-248. (in Chinese)

[11] Y. Fan, Key Words: Makerspace, [J]. China Employment, (2016) No.6, p.56-56. (in Chinese) 